\title{
Waterlogged wasteland treatment through agro-forestry: A review
}

\author{
S. Sarvade ${ }^{1 *}$, D. S. Gautam ${ }^{1}$, D. Kathal ${ }^{1}$ and Prabhat Tiwari ${ }^{2}$ \\ ${ }^{1}$ College of Agriculture, Balaghat, Jawaharlal Nehru Krishi Vishwa Vidyalaya, Jabalpur-482004 (Madhya \\ Pradesh), INDIA \\ ${ }^{2}$ Department of Silviculture and Agroforestry, Dr. YS Parmar University of Horticulture and Forestry, Nauni, Solan \\ - 173230 (Himachal Pradesh), INDIA \\ *Corresponding author. E-mail: somanath553@gmail.com
}

Received: July 21, 2016; Revised received: December 19, 2016; Accepted: January 5, 2017

\begin{abstract}
India covers 147.75 mha degraded area, whereas $6.41 \mathrm{mha}$ area confined to waterlogging problem in Bihar, Maharashtra, Gujarat, Uttar Pradesh, Orissa, West Bengal, Punjab, Tamil Nadu, Andhra Pradesh, Haryana, Kerala, Rajasthan and few other states. The transpiration principle of plants is used in bio-drainage treatment to reclaim such problematic areas sustainably. Evergreen broad leaved species recorded high transpiration rate and contribute highly in reclamation of waterlogged saline soils. Short rotation fast growing tree species like Salix, Eucalypt, Acacia, Albizia, Terminalia, Prosopis, Populus were the suitable species for such areas. Agri-silviculture, agri-horti-silviculture, silvi-pasture, multipurpose woodlots, strip plantation and boundary plantations were widely used for reclamation of saline-waterlogged conditions of India. In agri-silviculture system, Eucalypt based agroforestry systems are widely used for reclamation of waterlogged areas as compared to other woody plant based systems. $0.84-0.86 \mathrm{~m}$ total drawdown of ground water in 3 years Eucalypt tree species. The vertical and horizontal root spreading of tree species is one important character for capturing and transpiration of excess water from waterlogged area. From the present investigation, longest root system was recorded from Prosopis cineraria (20-60 m) species.
\end{abstract}

Keywords: Eucalypt, Ground water table, Transpiration rate, Waterlogged area

\section{INTRODUCTION}

India has only $2.4 \%$ of the world's land area and nourish $16.7 \%$ of the world's human population and $18 \%$ livestock. The human and livestock population continiously increases pressure on existing land resources for their daily needs. On the other hand, the country covers 147.75 mha area under different soil degradation classes explained by National Bureau of Soil Survey and Land Use Planning (NBSS \& LUP). Under these categories salt-affected soils spreads in $6.73 \mathrm{mha}$ (Million hectare) area and waterlogged in $6.41 \mathrm{mha}$ area (including 1.66 mha surface ponding and 4.75 mha subsurface waterlogging) (Anonymous, 2010). The area under salinization, alkalinisation and waterlogging was 3.2 mha according to National Remote Sensing Agency (NRSA) in the year of 1990; however, 21.7 mha was reported by Sehgal and Abrol (1994) in the year of 1994. Bihar, Maharashtra, Gujarat, Uttar Pradesh, Orissa, West Bengal, Punjab, Tamil Nadu, Andhra Pradesh, Haryana, Kerala, Rajasthan and few other states of the country are experiencing problems of waterlogging and salinity (Anonymous, 2009). Commission on Agriculture (1976) defined waterlogging as "Excess water in the root zone due to high wa- ter-table restricting the normal aeration of the crop roots". Heavy rainfall, poor drainage, excess irrigation, hard pan, shallow water table and seepage from canal cause the waterlogging problems (Pandey et al., 2015). The criteria for defining waterlogging and different types of area waterlogged are given in Table 1. Arid and semiarid regions of the country are affected mostly due to canal irrigation without provision of enough drainage, which increases water-table and secondary salinization problem.

For sustainable development, we have to reclaim such problematic areas and maximise the country's cultivated area. The reclamation processes includes biological, chemical and mechanical measures. Under biological measures, tree based systems have the potential to reclaim waterlogged and saline soils efficiently and sustainably by improving soil health quality. The short rotation, fast growing tree based agroforestry systems showed potential in bio-drainage treatment to prevent waterlogging in canal-irrigated areas (Singh and Pandey 2011; Fanish and Priya 2013).

\section{MATERIALS AND METHODS}

Data on plant species used in agroforestry systems of India and their potential transpiration rate is collected 
Table 1. Criteria adopted by Gov. of India and different type of waterlogged areas in India.

\begin{tabular}{ll}
\hline Type of water-logging & Standing water depth \\
\hline Waterlogged & $<2.0 \mathrm{~m}$ \\
Shallow lowland & $0-30 \mathrm{~cm}$ \\
Intermediate lowland & $31-50 \mathrm{~cm}$ \\
Semi deep lowland & $51-100 \mathrm{~cm}$ \\
Deep water lowland & $>100 \mathrm{~cm}$ \\
Potentially waterlogged & $2.0-3.0 \mathrm{~m}$ \\
Safe & $>3.0 \mathrm{~m}$ \\
\hline
\end{tabular}

(Source: Anonymous, 2009; Pandey et al., 2015)

from the scientific papers published in reputed journals (Agroforestry Systems, International Journal of Bioresource and Stress Management, Journal of Plant Stress Physiology, Current Science, Tropical Ecology, Indian Journal of Ecology, The Indian Forester etc.) and technical reports/bulletins of research institutes. On the basis of collected data this manuscript is formed for showing further research views in such areas.

\section{RESULTS AND DISCUSSION}

Bio-drainage: It may be defined as "pumping of ex-

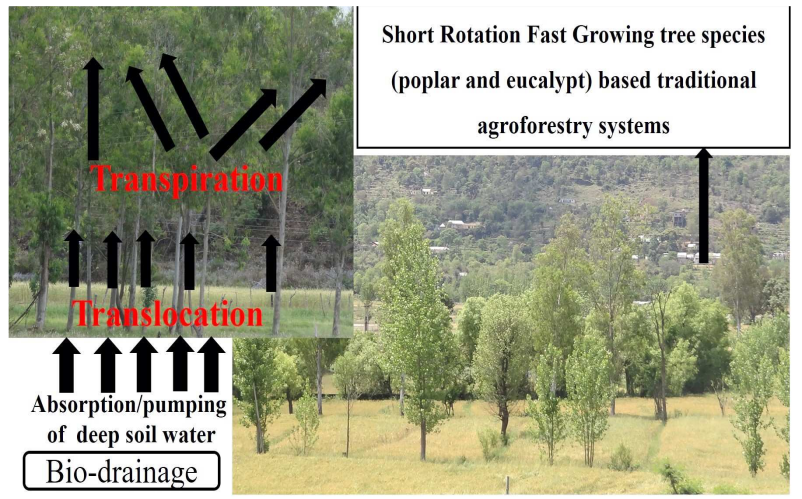

Fig. 1. Bio-drainage concept with an example of agro-forestry system.

cess soil water by deep-rooted plants using their bioenergy". The deep tree roots reached up to excess soil water and can pump out it easily without deteriorating the soil environment (Fig 1). The term bio-drainage first time documented by Gafni (1994), however earlier Heuperman (1992) used term bio-pumping to describe the use of trees for water table control. It uses the transpirative capacity of vegetation and especially

Table 2. Agro-forestry systems used for treating the salt affected-waterlogged areas of India.

\begin{tabular}{|c|c|c|c|}
\hline System & Tree component & $\begin{array}{llll}\begin{array}{l}\text { Crop } \\
\text { grass }\end{array} & \text { OR herb } & \text { OR } \\
\end{array}$ & Reference \\
\hline \multirow[t]{5}{*}{ Agri-silviculture } & Salix spp. & Wheat & Kumar et al., 2012 \\
\hline & Eucalyptus tereticornis & Rice/ Wheat & $\begin{array}{l}\text { Ram et al., 2007; Ram et al., } \\
\text { 2011; Wicke } \text { et al., } 2013\end{array}$ \\
\hline & $\begin{array}{l}\text { Eucalyptus tereticornis, Acacia nilotica, } \\
\text { Albizia lebbeck, } \\
\text { Terminalia arjuna, Prosopis juliflora }\end{array}$ & $\begin{array}{l}\text { agricultural } \\
\text { crops (basis of local } \\
\text { need) }\end{array}$ & Biswas and Biswas, 2014 \\
\hline & Populus deltoides & $\begin{array}{l}\text { Berseem, rice, wheat, and } \\
\text { mustard under }\end{array}$ & Singh, 2011 \\
\hline & $\begin{array}{l}\text { Eucalyptus tereticronis, Acacia nilotica, } \\
\text { Populus deltoides }\end{array}$ & $\begin{array}{l}\text { Rice-wheat, Guinea grass } \\
\text { (Panicum maximum)- } \\
\text { Oats, Rice-berseem, } \\
\text { Cowpea-berseem, Pi- } \\
\text { geonpea/sorghum- } \\
\text { mustard, turmeric }\end{array}$ & Singh et al., 1997 \\
\hline $\begin{array}{l}\text { Agi-horti- } \\
\text { silviculture }\end{array}$ & $\begin{array}{l}\text { Zizyphus mauritiana, Punica granatum, } \\
\text { Syzygium cumini, Emblica officinalis, } \\
\text { Tamarindus indica } \\
\text { Carissa carandus and Psidium } \\
\text { Guajava }\end{array}$ & $\begin{array}{l}\text { Egyptian clover, wheat, } \\
\text { onion, and garlic }\end{array}$ & Tomar et al., 2003 \\
\hline Silvi-pasture & $\begin{array}{l}\text { Prosopis juliflora, Acacia nilotica, } \\
\text { Casuarina equisetifolia, } \\
\text { Terminalis arjuna, Tamarix articulata, } \\
\text { and Pongamia pinnata }\end{array}$ & $\begin{array}{l}\text { Leptochloa fusca, } \\
\text { Chloris gayana, } \\
\text { Brachiaria mutica, and } \\
\text { Sporobolus spp. }\end{array}$ & $\begin{array}{l}\text { Singh, 2011; Singh et al., } \\
\text { 2014; Behera et al., } 2015\end{array}$ \\
\hline $\begin{array}{l}\text { Multipurpose wood- } \\
\text { lots }\end{array}$ & $\begin{array}{l}\text { Acacia nilotica, Albizia lebbeck, A. } \\
\text { procera, Azadirachta indica, Cassia } \\
\text { siamea, Casuarina equisetifolia, Euca- } \\
\text { lyptus tereticornis, E. hybrid, Leucaena } \\
\text { leucocephala, Pithecellobium dulce, } \\
\text { Pongamia pinnata, Prosopis alba, Pro- } \\
\text { sopis juliflora, Terminalia arjuna }\end{array}$ & - & $\begin{array}{l}\text { Dagar et al., 2001; Khan and } \\
\text { Shukla, 2003; Basavaraja et } \\
\text { al., 2007; Singh et al., 2008; } \\
\text { Behera } \text { et al., } 2015\end{array}$ \\
\hline Strip Plantation & $\begin{array}{l}\text { Eucalyptus tereticornis (c-3 and c-10), } \\
\text { Tamarix aphylla, Prosopis juliflora, } \\
\text { Terminalia arjuna }\end{array}$ & - & Toky et al., 2011 \\
\hline Boundary plantation & Eucalyptus spp. & - & Ram et al., 2008 \\
\hline
\end{tabular}


Table 3. Tree species used for bio-drainage treatment in salt affected waterlogged areas of India.

\begin{tabular}{|c|c|c|c|}
\hline Plant species & Tree Family & $\begin{array}{l}\text { Rate of tran- } \\
\text { spiration }\end{array}$ & Source \\
\hline $\begin{array}{l}\text { Acacia tortilis, A. nilotica, A. farne- } \\
\text { siana }\end{array}$ & Mimosoideae & $\begin{array}{l}2.63 \mathrm{~m} \mathrm{~mol} \\
\mathrm{~m}^{-2} \mathrm{~s}^{-1}\end{array}$ & $\begin{array}{l}\text { Devaranavadgi et al., 2005; Akram et al., 2008; } \\
\text { Dagar } \text { et al., } 2012\end{array}$ \\
\hline Albizia procera (Roxb.) Benth & Mimosoideae & & Arunachalam et al., 2014 \\
\hline Alnus cremastogyne, A. trabeculosa & Betulaceae & & Sharma, 2012; Arunachalam et al., 2014 \\
\hline Azadirechta indica & Meliaceae & $\begin{array}{l}2.88 \pm 0.2 \mathrm{gm} \\
\text { leaf }^{-1} \mathrm{hrs}^{-1}\end{array}$ & Pagare et al., 2014 \\
\hline Butea monosperma & Fabaceae & & Arunachalam et al., 2014 \\
\hline Callistemon lanceolatus & Myrtaceae & & Toky et al., 2011; Anonymous, 2013 \\
\hline $\begin{array}{l}\text { Casuarina spp. (C. gluaca, } C . \\
\text { equisaetifolia, C. obesa) }\end{array}$ & Casuarinaceae & & $\begin{array}{l}\text { Ram et al., 2008; Toky et al., 2011; Dagar et al., } \\
\text { 2012; Chaudhari } \text { et al., 2014; Pandey et al., } 2015\end{array}$ \\
\hline Dalbergia sissoo & Fabaceae & $\begin{array}{l}2.67-3.28 \mathrm{~m} \\
\text { mol. } \mathrm{m}^{-2} \mathrm{~s}^{-1}\end{array}$ & $\begin{array}{l}\text { Devaranavadgi et al., 2005; Anonymous, 2013; } \\
\text { Prasath } \text { et al., 2014; }\end{array}$ \\
\hline $\begin{array}{l}\text { Eucalyptus spp. (E. tereticonris, E. } \\
\text { calamdulensis; E. hybrid) }\end{array}$ & Myrtaceae & $\begin{array}{l}2.72-3.06 \mathrm{~m} \\
\mathrm{~mol} . \mathrm{m}^{-2} \mathrm{~s}^{-1}\end{array}$ & $\begin{array}{l}\text { Ram et al., 2007; Akram et al., 2008; Shakya and } \\
\text { Singh, 2010; Toky et al., 2011; Ram et al., 2011; } \\
\text { Dagar et al., 2012; Wicke et al., 2013; Chaudhari } \\
\text { et al., 2014; Singh et al., 2014; Arunachalam } \\
\text { et al., 2014; Pagare } \text { et al., 2014; Pandey et al., } \\
2015\end{array}$ \\
\hline Grevillea spp. & Protaceae & & $\begin{array}{l}\text { Chandel and Sharma, 2011; Arunachalam et al., } \\
2014\end{array}$ \\
\hline Leucaena Leucocephala & Mimosoideae & & Devaranavadgi et al., 2005 \\
\hline Melia azedarach & Meliaceae & & Toky et al., 2011 \\
\hline Morus alba & Moraceae & & Arunachalam et al., 2014 \\
\hline Parkinsonia aculeate & Caesalpinioideae & & Dagar et al., 2012 \\
\hline Pithecellobium dulce & Mimosoideae & & Sarala and Maheswari, 2012 \\
\hline Pongamia pinnata & Fabaceae & & $\begin{array}{l}\text { Ram et al., 2008; Toky et al., 2011; Pandey et } \\
\text { al., } 2015\end{array}$ \\
\hline Populus spp. & Salicaceae & $\begin{array}{l}13-200 \mathrm{gpd} \\
\text { tree }^{-1}\end{array}$ & $\begin{array}{l}\text { Anonymous 2009a; Chaudhari et al., 2014; Singh } \\
\text { et al., 2014; Arunachalam et al., } 2014\end{array}$ \\
\hline Prosopis juliflora, P. cineraria, & Mimosoideae & & Toky et al., 2011; Dagar et al., 2012 \\
\hline $\begin{array}{l}\text { Salix babylonica, } S . \text { monosperma, } S \text {. } \\
\text { xuchonensis }\end{array}$ & Salicaceae & $\begin{array}{l}10-50 \\
\text { tree }^{-1}\end{array}$ & Anonymous 2009a; Anonymous, 2013 \\
\hline Salvadora persica, S. oleoides & Salvadoraceae & & Pandey et al., 2015 \\
\hline Syzygium cuminii & Myrtaceae & & $\begin{array}{l}\text { Ram et al., 2008; Toky et al., 2011; Pandey et } \\
\text { al., } 2015\end{array}$ \\
\hline $\begin{array}{l}\text { Tamarix aphylla; } T . \text { troupii, } T . \text { ar- } \\
\text { ticulata }\end{array}$ & Tamaricaceae & & Akram et al., 2008; Toky et al., 2011 \\
\hline Taxodium distichum, T. scandens & Cupressaceae & $\begin{array}{l}0.3-18 \quad \text { gpd } \\
\text { tree }^{-1}\end{array}$ & Anonymous 2009a; \\
\hline Terminalia arjuna, & Combretaceae & & $\begin{array}{l}\text { Ram et al., 2008; Toky et al., 2011; Anonymous, } \\
\text { 2013; Pandey et al., } 2015\end{array}$ \\
\hline $\begin{array}{l}\text { Bamboos (Bambusa cacharensis R. } \\
\text { Majumder (Betua), B. vulgaris } \\
\text { Schrad. ex Wendl. (Jai borua) and } B . \\
\text { balcooa } \text { Roxb. (Sil borua). }\end{array}$ & Poaceae & $\begin{array}{l}2.58 \mathrm{~m} \mathrm{~mol} \\
\mathrm{~m}^{-2} \mathrm{~s}^{-1}\end{array}$ & $\begin{array}{l}\text { Nath and Das, 2012; Chaudhari et al., 2014; } \\
\text { Prasath et al., 2014; Arunachalam et al., } 2014\end{array}$ \\
\hline Brachiaria mutica & Poaceae & & Anonymous 2009a; Chaturvedi et al., 2011 \\
\hline $\begin{array}{l}\text { Dichanthium annulatum, D. carico- } \\
\text { sum }\end{array}$ & Poaceae & & Anonymous 2009a; Chaturvedi et al., 2011 \\
\hline Leptochloa fusca & Poaceae & & Anonymous 2009a; Chaturvedi et al., 2011 \\
\hline Panicum maximum & Poaceae & & Singh et al., 1997 \\
\hline Phragmites australis & Poaceae & & Anonymous 2009a; Chaturvedi et al., 2011 \\
\hline Cynodon dactylon & Poaceae & $\begin{array}{l}4.5-14.1 \mathrm{~mm} \\
\text { day }^{-1}\end{array}$ & Anonymous 2009a \\
\hline Sorghum bicolour & Poaceae & $\begin{array}{ll}2.0-9.8 & \mathrm{~mm} \\
\text { day }^{-1} & \end{array}$ & Anonymous 2009a \\
\hline Trifolium spp. & Fabaceae & $\begin{array}{ll}4.5-9.9 & \mathrm{~mm} \\
\text { day }^{-1} & \end{array}$ & Anonymous 2009a \\
\hline Typha spp. & Typhaceae & $\begin{array}{l}8.5-28.2 \mathrm{~mm} \\
\text { day }^{-1}\end{array}$ & Anonymous 2009a \\
\hline
\end{tabular}


S. Sarvade et al. / J. Appl. \& Nat. Sci. 9 (1): 44 - 50 (2017)

Table 4. Length and basal diameter of main and lateral roots of multipurpose tree species.

\begin{tabular}{lcccc}
\hline \multirow{2}{*}{ Tree Species } & \multicolumn{2}{c}{ Main Roots } & \multicolumn{2}{c}{ Lateral Roots } \\
\cline { 2 - 5 } & Length $(\mathbf{c m})$ & Basal diameter $(\mathbf{c m})$ & Length $(\mathbf{c m})$ & Basal diameter $(\mathbf{c m})$ \\
\hline Acacia catechu & $143 \pm 7.3$ & $8.6 \pm 3.1$ & $99 \pm 7.9$ & $2.4 \pm 0.3$ \\
Acacia nilotica & $215 \pm 7.8$ & $15.4 \pm 1.1$ & $139 \pm 10.8$ & $2.3 \pm 0.2$ \\
Albizzia lebbek & $118 \pm 36.8$ & $1.4 \pm 2.1$ & $141 \pm 16.7$ & $3.7 \pm 0.3$ \\
Azadirachta indica & $117 \pm 22.3$ & $12.2 \pm 1.4$ & $82 \pm 7.6$ & $2.5 \pm 0.2$ \\
Dalbergia sissoo & $130 \pm 17.0$ & $10.1 \pm 0.5$ & $134 \pm 11.9$ & $2.5 \pm 0.2$ \\
Melia azedarach & $92 \pm 6.7$ & $12.4 \pm 0.5$ & $66 \pm 3.50$ & $3.0 \pm 0.3$ \\
Morus alba & $72 \pm 6.2$ & $9.5 \pm 1.9$ & $160 \pm 13.6$ & $3.0 \pm 0.3$ \\
Prosopis cineraria & $288 \pm 43.3$ & $9.1 \pm 4.3$ & $157 \pm 20.2$ & $2.7 \pm 0.3$ \\
Zizyphus mauritiana & $102 \pm 1.8$ & $9.2 \pm 1.2$ & $112 \pm 14.0$ & $2.4 \pm 0.4$ \\
Populus deltoids & $85 \pm 10.4$ & $26.4 \pm 2.4$ & $271 \pm 60.9$ & $6.8 \pm 1.0$ \\
Eucalyptus tereticornis & $179 \pm 12.4$ & $17.9 \pm 1.0$ & $167 \pm 23.3$ & $3.5 \pm 0.3$ \\
Leucaena leucocephala & $148 \pm 32.7$ & $11.7 \pm 0.6$ & $72 \pm 6.3$ & $2.7 \pm 0.3$ \\
\hline
\end{tabular}

(Source: Toky and Bisht, 1992)

Table 5. Suitability of tree species for saline soils (Adopted from Dash et al., 2005).

\begin{tabular}{|c|c|}
\hline $\begin{array}{l}\text { Tolerant } \\
\left(\text { ECe 25-35 dS m }{ }^{-1}\right)\end{array}$ & $\begin{array}{l}\text { Tamarise troupii, T. artiaulata, Prosopis juliflora, Pithe cellobium dulce, Parkinsonia aculeata, } \\
\text { Acacia famesiana }\end{array}$ \\
\hline $\begin{array}{l}\text { Moderately tolerant } \\
\text { (ECe 15-25 dS m }{ }^{-1} \text { ) }\end{array}$ & $\begin{array}{l}\text { Callistemon lanceolatus, Acacia nilotica, A. pennatula, A. tortilis, Casuarina glauca 13144, C. } \\
\text { glauca 13987, C. obessa 27, C. glauca (FRJ), C. equisetifolia (FRJ), Eucalyptus camaldulensis, Leu- } \\
\text { caena leucocephala, Erescentia alata }\end{array}$ \\
\hline $\begin{array}{l}\text { Moderately sensitive } \\
\left(\text { ECe 10-15 } \mathrm{dS} \mathrm{m}^{-1}\right)\end{array}$ & $\begin{array}{l}\text { Casuarina cunninghamiana (FRJ), C. cunninghamiana (Aust.), Eucalyptus tereticomis, Acacia auri- } \\
\text { culiformis, Guazuma ulmifolia, Leucanea shannon ii, Samanea saman, Albizzia caribea, Senna } \\
\text { atomeria, Ferminalia arjuna, Pongamia pinnata }\end{array}$ \\
\hline $\begin{array}{l}\text { Sensitive } \\
\left(\text { ECe } 7-10 \mathrm{dS} \mathrm{m}^{-1}\right)\end{array}$ & $\begin{array}{l}\text { Syzgium cumimi, S. fruticosum, Tamarindus indica, Salix app., Acacia deanei, Albizia quachepela, } \\
\text { Alelia herbertsmithi, Ceaselpimia eriostachya, } C \text {. velutina, Halmatoxylon brasiletto }\end{array}$ \\
\hline
\end{tabular}

trees to reduce elevated ground water table of an area (Heuperman et al., 2002). Highly transpiring tree species selected to mitigate waterlogging conditions (Shakya and Singh, 2010). The average annual rate of transpiration was $3446 \mathrm{~mm}$ from a 25-ha plantation of Eucalyptus camaldulensis, Acacia nilotica, Prosopis cineraria and Ziziphus spp., in Rajasthan (Heuperman and Kapoor, 2003).

Short Rotation Fast Growing (SRFG) tree species such as Eucalyptus spp., Casuarina spp., Terminalia arjuna, Pongamia pinnata and Syzygium cuminii are used in bio-drainage treatment in waterlogged area of the country (Pandey et al., 2015). The different tree species, their growth rate, growing stage, density of plants and other soil and climatic conditions may affect biodrainage potential of tree species (Dash et al., 2005). Multipurpose tree species of different agroforestry systems used in bio-drainage treatment are given in Table 2. The use of bio-drainage treatment depends on ground water EC, when its value goes higher than 12 $\mathrm{ds} \mathrm{m}^{-1}$, bio-drainage cannot be workable due to accumulation of salt in tree plantation strips (Kapoor and Denecke, 2001).

Ram et al. (2011) reported 0.84-0.86 m total drawdown of groundwater in 3 years of April 2006, 2007 and 2008 under Eucalyptus tereticornis+wheat (clone C-7) in fields of Haryana (Northwest India), where 10 $\%$ area $(0.44 \mathrm{mha})$ is waterlogged resulting in reduced crop yields and abandonment of agricultural lands. They also reported 30.91 day $^{-1}$ tree $^{-1}$ average transpiration rate in the 5 year old E. tereticornis, which was
$268 \mathrm{~mm}^{\text {annum }}{ }^{-1}$ by 240 trees $\mathrm{ha}^{-1}$ against the mean annual rainfall of $212 \mathrm{~mm}$. Plantations of E. tereticornis act as bio-pumps and therefore, Ram et al. (2007 and 2011) recommend closely spaced parallel strip plantations in shallow ground water table (g.w.t.) areas of semi-arid regions with alluvial sandy loam soils. Behera et al. (2015) reported agri-silviculture, agi-horti -silviculture, silvi-pasture and multipurpose woodlots prominent systems for treating salty and waterlogged conditions. In case of agri-silviculture system, the rice, wheat, berseem, mustard, cowpea, pigeon pea, sorghum, turmeric and oat annual crops were successfully grown under Salix, Eucalypt, Acacia, Albizia, Terminalia, Prosopis, Populus tree species (Singh et al., 1997; Ram et al., 2007; Ram et al., 2011; Singh, 2011; Kumar et al., 2012; Wicke et al., 2013; Biswas and Biswas, 2014).

Tree-crop combinations under agri-horti-silviculture, silvi-pasture, multipurpose woodlots, strip plantation and boundary plantation with their reference are given in Table 2. Many scientists reported suitability of woody perennials in solving the problem of saltywaterlogged areas in India (Table 3). Among the all tree species, Eucalypt species was widely used in reclamation of waterlogged areas and reviewed more authors as compared to other tree species. The main and lateral root spreading of tree species is one important character for capturing water, vertical and horizontal spreading of root system covers more area for absorption and transpiration of excess water from waterlogged area. Prosopis cineraria have long (20-60 m) 
tap root system and high transpiration rate as compared to other desert plants (Gallacher and Hill, 2005). Toky and Bisht (1992) reported root (main and lateral) length of some multipurpose tree species (Table 4).

Lowering soil salinity: Tree based systems generally practiced for sustainable production of food material with improving soil properties (Sarvade et al., 2014a; Sarvade et al., 2014b). The physico-chemical properties of soil improve through decomposition of leaf litter added by perennial tree species (Sarvade et al., 2014c; Pawar et al., 2014). The amelioration of salt affected soils is mainly controlled by nature and type of tree species, growth habit, quantity and quality of litter produced, planting density, age of plantation, ability to fix $\mathrm{N}$, and management practices. The amelioration processes includes, lowering soil $\mathrm{pH}$, electrical conductivity (EC) (Tomar et al., 2003) and ESP; increases water holding capacity, as well as infiltration rate and hydraulic conductivity with soil fertility. Whereas, tree species minimizes the salt deposition in the upper layers of the soil and prevents salt accumulation on the surface layer (Behera et al., 2015). Table 5 explains category wise tree species suitable for saline soils.

\section{Conclusion}

The 6.41 mha area of India is confined to salt affected waterlogging problem. Reclamation of such areas is prime requisite for re-silencing the pressure of increasing human and livestock population. Among the different treatments, bio-drainage is one of the vegetation based systems used widely for treating waterlogged areas. In bio-drainage treatment, transpiration losses from tree species are basic principle. Agri-silviculture, silvi-pasture, agri-hori-silviculture, multipurpose woodlots, strip plantation and boundary plantations were widely used for bio-drainage treatment. Among all agroforestry systems, Eucalypt based agrisilviculture system was widely used vegetation system.

\section{ACKNOWLEDGMENTS}

Authors would like to thank the Dean, College of Agriculture, Balaghat for encouraging and providing assistance for writing the manuscript.

\section{REFERENCES}

Akram, S., Kashkouli, H.A. and Pazira, E. (2008). Sensitive variables controlling salinity and water-table in a biodrainage system. Irrigation and Drainage Systems, 22: 271-285.

Anonymous, (1990). IRS-Utilisation Programme: Soil Erosion Mapping. Project Report National Remote Sensing Agency. Hyderabad, India.

Anonymous, (2009). Assessment of waterlogging and salt and/or alkaline affected soils in the commands of all major and medium irrigation projects in the country using satellite remote sensing. Regional Remote Sensing Service Centre, Indian Space Research Organisation.
Jodhpur, New Delhi, 20.

Anonymous, (2009a). Phyto-technology Technical and Regulatory Guidance and Decision Trees, Revised. PHYTO-3. Washington, D.C., Interstate Technology \& Regulatory Council, Phyto-technologies Team, Tech Reg Update. Washington, DC. 204.

Anonymous, (2010). Degraded and wastelands of India status and spatial distribution. Indian Council of Agricultural Research, Pusa, New Delhi. 155.

Anonymous, (2013). A Handbook of Landscape-A Guide. Central Public Works Department, New Delhi. 154.

Arunachalam, A., Balasubramanian, D., Arunachalam, K., Dagar, J.C. and Kumar, B.M. (2014). Wetland-based agroforestry systems: balancing between carbon sink and source. In: Dagar, J.C. (Eds.), Agro-forestry systems in India: livelihood security and ecosystem services, Springer India. 333-344.

Basavaraja, P.K., Sharma, S.D., Badrinath, M.S., Sridhara, S. and Hareesh, G.R. (2007). Prosopis juliflora-An efficient tree species for reclamation of salt affected soils. Karnataka Journal of Agricultural Sciences, 20:727-31.

Behera, L., Nayak, M.R., Patel, D., Mehta, A., Sinha, S.K. and Gunaga, R. (2015). Agroforestry practices for physiological amelioration of salt affected soils. Journal of Plant Stress Physiology, 1(1):13-18.

Biswas, A. and Biswas, A. (2014). Comprehensive approaches in rehabilitating salt affected soils: A review of Indian perspective. Open Transactions on Geosciences, 1:13-24.

Chandel, R.S. and Sharma, B.L. (2011). Declining Himalayan bio-resources-a threat to farmer's livelihood. In: Short rotation forestry and Agroforestry: an exchange of experience between CDM countries and Europe. Marchesi di Barolo, Barolo, Italy. 67-75.

Chaturvedi, S., Kaushal, R., Tewari, S. and Dhyani, V. C. (2011). Agroforestry: an integrated land management option for fragile ecosystem. Journal of Functional and Environmental Botany, 1(1):45-53.

Chaudhari, S.K., Dagar, J.C. and Toky, O.P. (2014). Biodrainage: An eco-friendly tool for combating waterlogging. In: Chhonkar, P.K., Dureja, P. (Eds.), Research Education and Technology Policy Forum. NAAS News, 14 (1): 11-13.

Dagar, J. C., Singh, A. K., Singh, R. and Arunachalum, A. (2012). Climate change vis-a-vis Indian agriculture. Annals of Agricultural Research, 33(4):189-203.

Dagar, J. C., Singh, G. and Singh, N. T. (2001). Evaluation of forest and fruit trees used for rehabilitation of semiarid alkali soils in India. Arid land Research and Management, 15:115-33.

Dash, C.J., Sarangi, A., Singh, A.K. and Dahiya, S. (2005). Bio-drainage: an alternate drainage technique to control waterlogging and salinity. Journal of Soil and Water Conservation, 4(3\&4):149-155.

Devaranavadgi, S.B., Sajjan, A.S., Wali, S.Y., Pawar, K.N. and Hunshal, C.S. (2005). Influence of chickpea based agri-silvicultural system on soil nutrients and its economic feasibility. Karnataka Journal of Agricultural Sciences, 18: 63-66.

Fanish, S. A. and Priya, R. S. (2013). Review on benefits of agro forestry system. International Journal of Education and Research, 1(1): 1-12.

Gafni, A. (1994). Biological drainage-rehabilitation option 
for saline-damaged lands. Water and Irrigation, 337: 33-36

Gallacher, D and Hill, J. (2005). Status of Prosopis cineraria (ghaf) tree clusters in the Dubai Desert Conservation Reserve. Tribulus, 15.2: 1-9

Heuperman, A. F. (1992). Trees in irrigation areas; the biopumping concept. Trees and Natural Resources, 34:20-25

Heuperman, A.F. and Kapoor, A.S. (2003). Bio-drainage Status in India and Other Countries. Indian National Committee on Irrigation and Drainage. New Delhi Pp. $1-47$

Heuperman, A. F., Kapoor, A. S. and Denecke, H.W. (2002). Bio-drainage: Principles, Experiences and Applications. Knowledge Synthesis Report 6, International Programme for Technology and Research in Irrigation and Drainage (IPTRID), FAO, Rome Pp. 1-79

Kapoor, A.S. and Denecke, H.W. (2001). Bio-drainage and Bio-disposal: The Rajasthan Experience. In GRID, IPTRID's network magazine. 17

Kumar, S., Gupta, G. R., Kumar, M., Vishwakarma, S. K. and Pal, M. (2012). Influence of willow plantation on wheat under waterlogged soil of Uttar Pradesh. In: Improving Lives with Poplars and Willows. $24^{\text {th }}$ Session of the International Poplar Commission, jointly hosted by FAO and the Indian Council for Forestry Research and Education (ICFRE), Dehradun, India. 183

Nath, A.J. and Das, A.K. (2012). Carbon pool and sequestration potential of village bamboos in the agro-forestry system of northeast India. Tropical Ecology, 53(3): 287-293

Pagare, R.L., Pawar, K. and Nirgude, V. (2014). Evapotranspiration and transpiration rate of some tropical tree species. International Journal of Scientific Research in Biological Sciences, 1(2): 1-2

Pandey, D.S., Singh, S.P. and Singh, G. (2015). Underprivileged agriculture: retrospection and future prospects. In: Pandey, G.B. (Eds.), Compendium of Lectures on Management of Underprivileged Agriculture. Pant University of Agriculture and Technology, Pantnagar. 311p.

Pawar, G.V., Singh, L., Sarvade, S. and Lal, C. (2014). Litter production and soil physico-chemical properties influenced by different degraded sites of Tropical Deciduous Forest, Chhattisgarh, India. The Ecoscan, 8(3\&4): 349352

Prasath, C. N. H., Balasubramanian, A., Radhakrishnan, S., Sudarshan, A. and Jaisankar, I. (2014). Eco-physilogical behaviour of 2 year grown afforested tree in Tamil Nadu, South India. Journal of the Andaman Science Association, 19(2):181-184

Ram, J., Dagar, J.C., Lal, K., Singh, G., Toky, O.P., Tanwar, V.S., Dar, S.R. and Chauhan, M.K. (2011). Bio-drainage to combat waterlogging, increase farm productivity and sequester carbon in canal command areas of northwest India. Current Science, 100(11): 1673-1680

Ram, J., Dagar, J.C., Singh, G., Lal, K., Tanwar, V. S., Shoeran, S. S., Kaledhonkar, M. J., Dar, S .R. and Kumar, M. (2008). Bio-drainage: eco-friendly technique for combating waterlogging and salinity. Technical Bulletin: CSSRI/Karnal/9/2008, Central Soil Salinity Research Institute, Karnal, India, 24p.

Ram, J., Garg, V.K., Toky, O.P., Minhas, P. S., Tomar, O. S., Dagar, J. C. and Kamra, S. K. (2007). Bio-drainage potential of Eucalyptus tereticornis for reclamation of shallow water table areas in North-west India. Agroforestry Systems, 69: 147-165

Sarala, T.D. and Maheswari, J. (2012). Phytomonitoring of atmospheric pollution in a dry tropical environment using perennial trees. Asian Journal of Science and Technology, 4(12): 11-16

Sarvade, S., Singh, R., Ghumare, V., Kachawaya, D. S. and Khachi, B. (2014a). Agroforestry: An approach for food security. Indian Journal of Ecology, 41(1): 95-98

Sarvade, S., Mishra, H. S., Kaushal, R., Chaturvedi, S. and Tewari, S. (2014b). Wheat (Triticum aestivum L.) yield and soil properties as influenced by different agrisilviculture systems of Terai region, Northern India. International Journal of Bio-resource and Stress Management, 5(3): 350-355

Sarvade, S., Singh, R., Prasad, H. and Prasad, D. (2014c). Agroforestry Practices for improving soil nutrient status. Popular Kheti, 2(1): 60-64.

Sehgal, J. and Abrol, I.P. (1994). Soil degradation in India: status and impact; Oxford and IBH: New Delhi, India. 80 .

Shakya, S.K. and Singh, J.P. (2010). New drainage technologies for salt affected waterlogged areas of southwest Punjab, India. Current Science, 99(2): 204-212

Sharma, R. P. (2012). Modelling dry matter allocation within Alnus nepalensis D. Don trees in Nepal. International Journal of Biodiversity and Conservation, 4(2): 47-53

Singh, G. (2011). Agroforestry models for rehabilitation of sodic soils. In: Production Technology and Management of Agroforestry Models. Udaipur: Agrotech Publishing Academy Pp. 27-34

Singh, G., Bhati, M., Rathod, T. R. and Tomar, U.K. (2014). Physiological responses to nutrient accumulation in trees seedlings irrigated with municipal effluent in Indian desert. Physiology Journal, 2014: 1-15

Singh, G., Singh, N.T., Dagar, J.C., Singh, H. and Sharma, V.P. (1997). An evaluation of agriculture, forestry and agroforestry practices in a moderately alkali soil in North-western India. Agroforestry Systems, 37:279-295.

Singh, S. K., Singh, R., Kumar, S., Narjary, B., Kamra, S. K. and Sharma, D.K. (2014). Productive utilization of sodic water for aquaculture-led integrated farming system: a case study. Journal of Soil Salinity and Water Quality, 6 (1): $28-35$

Singh, V. S. and Pandey, D. N. (2011). Multifunctional agroforestry systems in India: science-based policy options. Climate Change and CDM Cell, Rajasthan State Pollution Control Board, Jaipur. 23p.

Singh, Y.P., Sharma, D.K., Singh, G., Nayak, A.K., Mishra, V.K. and Singh, R. (2008). Alternate land use management for sodic soils. Uttar Pradesh: Central Soil Salinity Research Institute, Regional Research Station, Lucknow. 16 p.

Singh, Y. P., Singh, G. and Sharma, D. K. (2014). Bioamelioration of alkali soils through agroforestry systems in central Indo-Gangetic plains of India. Journal of Forest Research, 25: 887-96

Toky, O.P., Angrish, R., Datta, K.S., Arora, V., Rani, C., Vasudevan, P. and Harris, P.J.C. (2011). Biodrainage for preventing waterlogging and concomitant wood yield in arid agro-ecosystems in North-western India. Journal of Scientific and Industrial Research, 70: 639-644 
Toky, O.P. and Bisht, P. (1992). Observations on the rooting patterns of some agro forestry trees in an arid region of North-western India. Agroforestry systems, 18: 249-261.

Tomar, O.S., Minhas, P.S., Sharma, V.K., Singh, Y.P. and Gupta, R.K. (2003). Performance of 31 tree species and soil conditions in plantation established with saline irrigation. Forest Ecology and Management, 177: 333-346

Wicke, B., Smeets, E.M.W., Akanda, R., Stille, L., Singh,
R.K., Awan, A.R., Mahmood, K. and Faaija, A.P.C. (2013). Biomass production in agroforestry and forestry systems on salt-affected soils in South Asia: Exploration of the GHG balance and economic performance of three case studies. Journal of Environmental Management, 127:324-334 